Table 2. EFfect of Calcium on Alginate GeL Calcium chloride in sea-water agar base $(\%)$ 0 $0 \cdot 1$ $0 \cdot 25$ 0.5
1.0 Syneresis
-
+
++
++ Gel strength Activity of alginase carrageenovor Liquefaction Liquefaction Pit $25 \mathrm{~mm}$ Pit $25 \mathrm{~mm}$
Pit $10 \mathrm{~mm}$

purpose calcium is added to a soil extract agar medium and the sodium alginate is dissolved in an aqueous solution of dipotassium hydrogen phosphate.

Atlantic Regional Laboratory,

W. YAPHE

National Research Council, Halifax, Nova Scotia.

1 Yaphe, W., Bact. Proc., 46 (1961).

2 Thjøtta, Th., and Kåss, E., Avhandl. Norske Videnskaps-Akad., Oslo 1, Mat.-Naturv. Klasse., No. 5, 3 (1945)

${ }^{3}$ Waksman, S. A., Carey, C. L., and Allen, M. C., J. Bact., 28, 213 (1934).

- Wieringa, K. T., Proc. Fourth Cong. Intern. Mikrobiol., 4, 482 (1949)

${ }^{5}$ Hugh, R., and Leifson, E., J. Bact., 66, 24 (1953).

'McDowell, R. H., Properties of Alginates, 17 (Alginate Industries Ltd., London, 1955).

7 Yaphe, W., Canad. J. Bot., 37, 751 (1959).

Skerman, V. B. D., A Guide to the Identification of the Genera of Bacteria, 182 (The Williams and Wilkins Co., Baltimore, Md., 1959).

\section{Aminopterin as an Inducing Agent in Bacteriocinogenic Bacteria}

INDUCTION of lysogenic bacteria was first produced by the use of ultra-violet light ${ }^{1}$. It was shown later that other radiations ${ }^{2}$, nitrogen mustard, ethyleneimines, epoxides and organic peroxides ${ }^{3}$ can also induce lysogenic bacteria to produce phage. The process of induction is not yet clear. Several lines of evidence indicate that the primary lesion initiated by inducing agents could be an alteration in the nucleic acid economy of the host, an effect of unbalanced growth 4 .

In $1952^{5}$ it was demonstrated that exposure of bacteriocinogenic bacteria to ultra-violet light induces the production of bacteriocin. The fact that phage production and bacteriocin formation are induced by the same agents, and many other similarities ${ }^{6}$ suggest that the mechanism of induction might be analogous in both systems. Since bacteriophage production appears to be the more complex of the two systems, it may be easier to study the triggering effect of induction in the case of bacteriocins.

The experiments described here were performed using strain $P$ of Pasteurella pestis, which produces bacteriocin, when irradiated with ultra-violet light ${ }^{7,8}$ or when treated with mytomycin $C^{8}$. Cultures of exponentially grown cells start to produce bacteriocin almost immodiately after irradiation ${ }^{7}$, that is, too early for the resumption of DNA synthesis to occur. If DNA synthesis is, inde日d, not needed for bacteriocin production (in contrast to phage production), the system will permit the demonstration of triggering the induction even by a substance which will stop synthesis of DNA completely.

Aminopterin (California Corporation for Biochemical Research), when given in a dose of $200 \mathrm{r} / \mathrm{ml}$., induces the $P$ strain of $P$. pestis to produce bacteriocin. In a typical experiment, $200 \mathrm{r} / \mathrm{ml}$. of aminopterin was added to a sample of an exponentially grown culture of Pasteurella pestis in synthetic medium ${ }^{10}$. Another sample was irradiated with ultra-violet light. The tubes containing these samples and the control were immersed in a water bath at $37^{\circ} \mathrm{C}$, for $3 \mathrm{~h}$. Chloroform was then added to each culture, to kill the bacteria, and bacteriocin (pesticin) in the medium titrated after decantation, as described previously ${ }^{7}$. The titre of the control was less than $1 \times 10^{2}$ arbitrary units/ml., the titre of the irradiated culture $1 \times 10^{4}$ and that of the aminopterin-treated culture $5 \times 10^{3}$ arbitrary units $/ \mathrm{ml}$.

Attempts to reverse induction of aminopterin by thymine, thymidine, folic acid or folinic acid have failed so far, both when these metabolites were added to the bacteria $1 \mathrm{~h}$ before or immediately after induction.

Israel Institute for Biological Research, Ness-Ziona. 2 Lwoff, A., Siminovitch, L., and Kjeldgaard, N., Ann. Inst. Pasteur,
79, 815 (1950).

2 Latarjet, R., Ann. Inst. Pasteur, 81, 389 (1951).

${ }^{3}$ Lwoff, A., Bact. Rev., 17, 269 (1953).

- Melechen, N. E., and Skaar, P. D., Fed. Proc., 19, 410 (1960).

s Jacob F., Siminovitch, L., and Wollman, E., Ann. Inst. Pasteur, 84, 313 (1952).

- Jacob, F., and Wollman, E., Bacteriophages, 374 (Interscience Pub., Ltd., London, 1959)

'Ben-Gurion, R., and Hertman, I., J. Gen. Microbiol., 19, 289 (1958).

${ }^{8}$ Hertman, I., and Ben-Gurion, R., J. Gen. Microbiol., 21, 135 (1959).

'Ben-Gurion, R. (unpublished results).

${ }^{10}$ Jackson, S., and Burrows, T. W., Brit. J. Exp. Path., 37, 570 (1956).

\section{GENETICS}

\section{Apparent Genetic Recombination in a Blue-Green Alga}

THE blue-green algae (Myxophyceae) have generally been thought to be devoid of sexuality ${ }^{1,2}$, although no genetical evidence for or against this supposition seems to have been reported so far. This communication describes experimental results obtained with a unicellular blue-green alga, generally known as Anacystis nidulans (Myers' strain), which seem to indicate the occurrence of sexual or parasexual phenomena in this organism.

From the wild-stock, strains of the alga which are, inter alia, about ten times as resistant to penicillin and streptomycin as the sensitive (parent) strain were derived by a few sub-cultures in basal medium (slightly modified Medium $C$ of Kratz and Myers ${ }^{3}$, diluted with equal parts of water) supplemented with gradually increasing concentrations of the respective antibiotic. These strains seem stable; a streptomycinresistant strain has been passed through 40 subcultures in the absence of streptomycin without having lost its resistance.

Each of the resistant strains was tested for crossresistance to the other antibiotic and found not to be cross-resistant. They were also inoculated-sepa. rately and jointly-into media which contained both the antibiotics. No growth was found to have occurred in any case even after six weeks.

Inocula from streptomycin-resistant and penicillinresistant strains were then transferred together into the basal medium containing no antibiotics. At various times, inocula were withdrawn from the mixture and transferred to culture flasks containing both the antibiotics. Out of a total of 36 such flasks (in different experiments) growth occurred in 10. Two typical growth-curves are shown in Fig. 1. The duration of the lag-phase was found to vary from 8-13 days. Since neither of the strains can by itself grow in flasks containing both streptomycin and penicillin, in contrast to inocula from the basal mix of the two strains which can, it is highly probable that growth in the latter case is due to the appearance of 